its former status in most parts of the country and is now commonly seen in many districts where the American grey squirrel is not present. Even within the area occupied by the grey squirrel, red squirrels have frequently been seen during the past two years. The American grey squirrel, after its severe setback in 1931, due mainly to disease, was in comparatively low numbers during 1932 and 1933, but there are now many indications that a period of increase is well on the way. It has gradually extended its range, spreading outwards from the main areas previously occupied (home counties, Midlands, Central Yorkshire, Cheshire, North Wales, Dumbartonshire, Fife and the environs of Bournemouth, Exeter and Edinburgh); several have been found in an isolated wood near Woodbridge, in Suffolk. "Should the numbers increase greatly over this large area," adds Mr. Middleton, "it seems probable that the grey squirrel may become of more serious economic importance than hitherto." The Oxford University Bureau is now extending its national investigations of animal numbers to the Japanese deer (Cervus sika) which have escaped from many English parks and taken to living wild in the woods of the home counties and the south, and of harvest. bugs (Trombidiidae).

\section{Scientific Correspondence of Sir James Smith (1759-1828)}

The main portion of Part 1 of the Catalogue of Manuscripts in the Library of the Linnean Society of London is devoted to the scientific correspondence of the first president of the Linnean Society, and Mr. Warren Dawson has abstracted the more important matters referred to in more than 3,000 letters received by Sir James Edward Smith (1759-1828) (Catalogue of the Manuscripts in the Library of the Linnean Society of London, Part 1. The Smith Papers. The Correspondence and Miscellaneous Papers of Sir James Edward Smith, M.D., F.R.S., First President of the Society. By Warren R. Dawson, F.R.S.E. Pp. 114. London: The Linnean Society, 1934. 10s. net). It is a careful piece of work, the completion of which confers a benefit on all who are interested in the natural history of the period immediately following Linnæus's death, and the transference of his collections to England six years later. The correspondents include many distinguished naturalists both at home and abroad, and some of their letters are valuable documents from the point of view of the history of biology. Sir James Edward Smith was primarily a botanist, but as possessor of Linnæus's collections for about forty-five years he had wide interests as a naturalist. $\mathrm{He}$ was one of the founders of the Linnean Society of London, his co-founders being the Rev. Samuel Goodenough, afterwards Bishop of Carlisle, and Thomas Marsham, an entomologist.

\section{International Aspects of Drug Addiction}

IN the Norman Kerr Memorial Lecture on this subjert published in the January issue of the British Journal of Inebriety, Sir Malcolm Delevingne, late Deputy Permanent Under-Secretary of State and
British representative on the Opium Advisory Committee of the League of Nations, showed that the international treatment of the problem during the last fourteen years has afforded a striking example of what can be accomplished in a difficult field by international co-operation, aided by the machinery of the League of Nations. After a historical sketch of the subject with special reference to the conferences at the Hague and Geneva, he dealt with the present position, showing that a system of control over the export and import trade is in operation, which if universally and effectively adopted is practically watertight. The illicit traffic however still continues to flourish, owing to a resort having been made to clandestine sources of supply or to parts of the world where control is less strict or nonexistent. In dealing in conclusion with the medical and scientific aspects of the problem, Sir Malcolm briefly alluded to the treatment and after-care of the addict, the possibility of replacing the drugs wholly or partly by less dangerous substances, the rate of consumption of the drugs in different countries, and the question as to whether new drugs are habitforming or not.

\section{Engineering Research in Japan}

IN vols. 10 and 11 of the Japanese Journal of Engineering recently issued by the National Research Council of Japan (Imperial Academy House, Veno Park, Tokyo), abstracts of varying length are given of some 400 papers on civil engineering, naval architecture, technology of ordnance, electrical engineering, mine engineering and metallurgy. The abstracts are printed in English, and about three-quarters of them relate to various aspects of electrical engineer. ing. Some of the papers have been contributed to the Institution of Electrical Engineers of Japan, while others contain reports of researches carried out at the Electrotechnical Laboratory, Ministry of Communications, Tokyo, and at research institutions and universities. Corresponding journals issued by the National Research Council contain abstracts of papers on astronomy, chemistry, physics, botany, zoology and other branches of science.

\section{Contour Maps of the East}

Among the latest additions to Bartholomew's General World Series are maps of the Middle East (Persia, Iraq, Palestine, Syria, Turkey and North Arabia) and the Far East (China, Japan, Korea and Manchukuo) on scales respectively of $I: 4,000,000$ and $1: 6,000,000$. The maps are contoured and layercoloured in green, brown and purple. Political and provincial boundaries are clearly marked, and on the map of the Middle East the chief roads, routes and caravan tracks are shown, as well as airports. All railways and the principal steamer routes are given. The scale allows a considerable amount of detail and a large number of names. The printing is clear, and the maps should prove most useful. The price of each map mounted on cloth and folded is six shillings. 